\title{
Gender Ventriloquism in Studio Production
}

\author{
Helen Reddington \\ University of East London \\ helenr@uel.ac.uk
}

\begin{abstract}
A process of ventriloquism, with male producers speaking through the mouthpieces of the women they produce, can reinforce gender delineations in pop. After discussing ventriloquism in pop and demonstrating different ways in which this has happened using historical examples, the author's original interviews with women who record male artists are examined to discover whether a similar process takes place when roles are reversed. The author concludes that aspects of ventriloquism are inherent in production, although some women producers have questioned gender roles during this process. She also notes that as more female mediators enter the profession, we may hear more authentic expressions of women's identities in popular music.
\end{abstract}

KEYWORDS: ventriloquism, recording, women producers and engineers

\section{Introduction}

At the 2014 Art of Record Production conference in Oslo, the US recording engineer Susan Rogers (who worked with Prince in the 1980s) described me a discussion she had with a group of women engineers about male vocalists, during which she realized that this was the first time she had ever experienced a situation that must have been quite normal in the record industry: that of studio professionals of one gender discussing the aesthetic qualities of the singing voices of the otherincluding what they found 'sexy' (Rogers 2014). This time however, in a reversal of normal practice, the mediators were female, and the vocalists were male. This observation by Rogers threw into relief the implications for female vocalists of the aesthetics of their performances being mediated almost exclusively by male engineers and producers who are positioned as audio gatekeepers, and therefore aesthetic arbiters, of what we listen to in mainstream popular music. As a result of this, I revisited previous conversations, having interviewed Rogers as part of a wider-ranging study of women producers and engineers (Reddington, forthcoming), and began to incorporate closer questioning about women's practices of recording 
male artists into later interviews. During this process, a question was raised: do producers speak through the artists they record, using them as mouthpieces? If so, this co-optation of the perceived agency of the recording artist, whether male or female, could be said to constitute an act of ventriloquism. This has political implications: when a male producer is mediating a female artist, an illusion of powerful womanhood can be articulated through her voice, a voice that has actually been processed through aesthetic decisions made by the male producer. Jason Toynbee's comparison of the use of studio technology to ventriloquism, noting men's control of the recording process (2000: 100), leads us to question exactly whose voice we are listening to when we hear pop music. The gendered control of recording raises similar issues to the gendered control in film, of which the film theorist Laura Mulvey (1975) observed that women have historically been "bearers of meaning rather than makers of meaning" (1975: 27). Mulvey's work has often been cited in critiques of music videos that prioritize the male gaze. Likewise, the "male ear" (defined by the composer Pia Palme on the website femalepressure.net in May 2016) ${ }^{1}$, has hitherto been an accepted aspect of the recording industry. Like the male gaze, the male ear is hidden and its power exercised behind the scenes, covertly exerting its influence on our perception of gender, according to Tara Rodgers (2010) who notes that "ideologies of sound production circulate unmarked for a particular politics of gender" (2010: 15). This happens in music making itself, in whose practice, according to Lucy Green, "delineations present themselves to us in musical experience, as if they were autonomous, immediate truths" (1997: 131).

Within the context of gendered musical labour in pop, however, music production forms part of a $21^{\text {st }}$ century landscape where traditional roles have increasingly been challenged. For example, in 2012 the Performing Right Society published a breakdown of gender percentages in song writing, arranging, and production that demonstrated exactly how male dominated these roles were despite, as the article acknowledged, the international successes of artists such as Adele and Emeli Sandé. The Music Producer's Guild, "with women making up less than four percent of its members" according to PRS' M Magazine (2012), must have found the figures alarming. Four years after the article was originally published, five female practitioners won MPG awards out of a total of sixteen in a move possibly stimulated by the article (the previous year it had been only one out of fifteen). Gendered production practices in the music industry have frequently irritated women artists, because lack of equality is bound to affect the content of what is being released. Some women feel powerful enough to speak out about them. In 2008, Björk expressed frustration on her website about the lack of credit she was given for her own skills in music technology, while her male collaborators were always lauded for their technical input (Nicholson 2008). Other high-profile artists have found ways to voice their concerns. Examples include the 2013 BBC 6 Music John Peel Lecture by Charlotte Church's about sexism in the music industry (BBC 2013), Laura Marling's project Reversal of the Muse (Marling 2016), which celebrates women's achievements in music, Grimes' regular tweets about her autonomy in the studio (Grimes 2008) and Missy Elliott's Twitter response to Billboard's 'Where are all the Female Producers?' lament (Elliott 2018). In academia, different facets of the industry have been increasingly critiqued for their gender politics, including studio practice (Wolfe 2012, 2016), digital music and sound art (Born and Devine 2016), DJ Culture (Gadir 2016), and music industry hierarchies (Leonard 2016). The many successful and established female producers (for example Joni Mitchell, Kate Bush, Linda Perry, and Missy Elliott) have often 
appeared as lone voices in a landscape populated by men who have ready access to studio technology. According to Jacques Attali (1999: 87), "Possessing the means of recording (...) allows one to impose one's own noise and to silence others". If we interrupt "The androcentric view [that] is (...) continuously legitimated by the very practices that it determines" (Bourdieu 2001:32), we may also discover new sources of creativity in the process of changing gender relations in the studio.

In this article, I will discuss various ways in which ventriloquism works in the recording of popular music by male producers, before introducing original interview material in which female producers and engineers address their own approaches to recording male vocalists. Aspects of this practice will be examined in order to demonstrate whether they also employ ventriloquism in their roles as mediators in the recording studio.

\section{Ventriloquism, Women's Voices and Agency}

Ventriloquism as a concept has been associated with the performing arts ever since the idea of separating the voice from the body became an intrinsic part of theatrical practice. According to Richard Middleton (2006), who pinpoints changes in18th century theatre practice as a key point for disembodiment in performance when "the projected voice, the voice thrown elsewhere" became commonplace (2007: 22). Middleton traces this through to present day popular music, where "the voice of the people is always plural, hybrid, compromised" (2006: 23). The advent of recording amplified these acts of "throwing of voices", according to Toynbee (2000), when singing into microphones encouraged vocalists to create specific singing styles designed for, and affected by, the use of the microphone (2000: 7677; also see Katz 2010). This highlighted the potential artificiality of making a sound recording of a voice that could exist separately from the sound source itself.

Transplanted voices soon began to be used to augment the visual aesthetics of conventional beauty. In 1931, the possibilities of matching the beautiful singing of a woman who was a "sore trial for the eye", with a physical presence that "may be accepted by the audience for a Venus" had been discussed by the composer Leopold Stokowski, for his hypothetical recording of Wagner's Tannhauser (Stokowski quoted in Milner 2009: 67). Movie making facilitated the throwing of voices, because as soon as films could talk, any mismatch perceived between listening to and seeing beauty became problematic (Fleeger 2014) leading to the employment of singers to ghost the voices in musical films. ${ }^{2}$ This was often distressing for the actors, who were not always informed of the substitution, and was later parodied in the film Singin' in the Rain (dir. Donen and Kelly 1953). The film exposed the narrative in which technology can be used to dislocate voices from the bodies from which they originated, and assign them to Venus-like figures.

In the music industry, the overlap between song writing and the act of recording creates different but arguably just as powerful acts of ventriloquism by producers. John Shepherd noted that it is a male trait to "demonstrate [his] power and influence (...) through a masculinized version of femininity" (1991: 169), and historical examples of this manifestation of power through the co-optation of women's recorded vocal personae augment the debate on male hegemony in the world of popular music recording. For instance, in pop music, the practice of male songwriters writing the female experience has long been accepted, and in this the "masculinized version of femininity" described by Shepherd can be easily identified as ventriloquism. The writers and producers of USA girl group music of the 1960s detailing teenage girls' perspectives were frequently male, despite the work of artists 
such as the lyricist Cynthia Weil and producer and writer Ellie Greenwich. Charlotte Greig (1989), who wrote a detailed history of the genre, criticized lyricist Eddie Holland's "time spent listening to women talking about their views, their problems and so on" for its "coldly manipulating" attitude, observing that "only through women could men make public their private and shamefully human emotions" (1989: 135). Barbara Bradby (1990) lauded the feisty sonic personae of these girl group singers. But from a twenty-first century viewpoint, the co-optation of youthful, female aura by (often older) men takes on an unwholesome perspective (see also Warwick 2004). The absurdity of this type of ventriloquism was later criticized by Judith Butler (1993), who described Aretha Franklin's 1967 recording of "You Make me Feel Like (A Natural Woman)" (whose music was written by Carole King, lyrics written by Gerry Goffin, and title suggested by producer Jerry Wexler) as that of a "drag queen" because the natural woman of the title was a male-constructed fantasy.

Traditional recording practice has also celebrated the idea of the auteur producer, whose sonic signature is instantly recognizable in their work, and whose drive to create perfect music governs their relationships with the musicians they work with. Phil Spector is frequently cited as an example of this type of Svengali producer, playing a manipulative (and often creatively disempowering) role that is still recognized in the music industry. In her biography, Darlene Love (2013) describes Spector using her voice on tracks purportedly performed by girl group The Crystals without her knowledge (2013: 82). More than a decade later, Nile Rogers revealed an equally dismissive attitude to his female artists, according to Daryl Easlea:

(...) we can make your secretary a star - all she's got to do is what we tell her to do. Point us to somebody in this building who is not a star and we will make them a star, no matter who it is, because we're going to make the record and our rhythm section is the star, we'll just put whoever in it (2004: 134).

Seemingly powerful women have continued not to be immune to the control of male production teams. Kay Dickinson (2001) discussed the degree of Cher's agency in the 1998 hit "Believe" (one of the most well-known songs featuring a highly-processed female vocal), illustrating the complexity of authorship in recording situations. The Cher effect is still sometimes used as a descriptor for the Antares Autotune sound processor, attributing the distinctive sound to her, yet the decision to use the vocal effect in the choruses was actually made by the producers (but Cher herself chose the telephoney sound used in the verses according to Sillitoe and Bell 1999). More importantly, "Believe" was written by a production team consisting of seven men, which is paradoxical, given its status as a song of female empowerment. A transaction occurred in the studio that acknowledged Cher's role as "bearer of meaning" (Mulvey 1975); her aura was a vital part of the successful commercial package. However, this process still constituted a recuperation of female empowerment (or perhaps co-recuperation, if we take into account Cher's collaboration). Such practice continues to be normal in pop music in the $21^{\text {st }}$ century. For instance, Beyoncé's hit song, "Run the World (Girls)", was written by a five-man writing team alongside Beyoncé herself, if we include the use of samples from other producers. There is something deeply ironic about female power being articulated by men through the mouthpieces of successful women artists that they produce, creating acts of ventriloquism that are so common that they can seem innocuous. The co-optation of the concept of female empowerment, and the male 
voicing of the female experience, is occasionally brought out into the open. Here, Lauren Mayberry of Chvrches described her disappointment at the discovery that Avril Lavigne's songs had been written by men:

I was totally the target audience (...) The marketing campaign was 'She's just like you. She writes the songs'. To a teenage girl writing songs in her bedroom, that's amazing. And then I woke up one day and realised [sic] it was all written by The Matrix [songwriting and production team]. Teenage me still loves that record [Let Go], but why did they sell it like that? I was pissed off that it was being sold as real. (Nicholson 2015)

There can be considerable tension between young female artists and older male collaborators who appear to appropriate their feisty, youthful aura. The singer Kelly Clarkson recently complained about her own lack of agency: "I just think it's funny that all these middle-aged guys told me, 'You don't know how a pop song needs to sound'. I'm a twenty-three-year-old-girl! But I was fighting those battles alone" (Seabrook 2015: 137).

Just as multi-tracking had facilitated the removal, repositioning, and processing of individual recorded tracks (Théberge 1997: 169, 179), the introduction of sampling further facilitated the alteration of sonic meanings. It could be used to reproduce patriarchal values, making the sound of the voice a commodity belonging to the sonic palette of the producer, rather than belonging to the vocalist who originally created it. As an example of this, Bradby (1993) analyzed the significance of the band Black Box's sampling of Loleatta Holloway's voice for their 1989 hit "Ride On Time". The track was mimed in the accompanying video by the much younger, slimmer model Katherine Quinol. The complex gender implications around this process, and an eventual court case, demonstrated that the public and the courts were strongly on the side of the artist whose vocal persona had been appropriated (1993: 155-176). Holloway eventually became "disco's most sampled artist", much to her dismay (Lawrence 2015). Camille Yarborough's voice was similarly "digitally neuter[ed]" by Norman Cook's cut-up techniques in his track "Take Yo' Praise" (Katz 2010: 158). When only a disembodied sound remains, it is possible to substitute any visual representation of a woman, tamper with the meaning of the performance, or de-gender her at will, thus fulfilling the prophesy of the Stokowski's dream of the beautiful woman becoming the mouthpiece for the voice of another (arguably less conventionally attractive) singer. By reconfiguring voice as sound, the producers position themselves as a ventriloquists, speaking, or rather singing, for the artist, regardless of his or her gender. For a male artist this may be playful (Auner 2003), but for a woman it can be disempowering.

Democratizing developments in studio technology the late $20^{\text {th }}$ century might have been expected to encourage more women to become involved in studio production in order to take control over their own music, according to Andrew Goodwin (1992). He expressed disappointment that the female instrument, the keyboard, which used to drive the newly-invented midi technology, had not led to an increase in women producers, although theoretically this technology allowed anybody (with the money and the time to learn new programs) to record, and this anybody did not have to be a male anybody. Progress has been slow, more than 25 years later, Paula Wolfe's (2012) research into self-production by female artists examines the benefits of privacy for learning and experimentation with a laptop computer with music software "in a studio of one's own", before presenting a musical fait accompli to a band or a studio team (Wolfe 2012). However, demonstrating the resilience of traditional studio roles, the journalist Art Tavana 
(2016) questions the ways in which male and female artists use the music program Garageband in the production process. He documents different integration levels of the program into the end product. The musician Grimes, for instance, retains control over her work right through to the final stages, while in the case of Dum Dum Girls' songwriter Dee Dee, her producer Richard Gottehrer needs to "enhance a lot of what she does in Garageband" (Tavana 2015). The article implies that GarageBand is actually a poor replacement for proper producers, who sometimes allow interesting (and presumed accidental) musical features to filter through to the final product. Georgina Pringle, an artist interviewed by Tavana, hints at the technosnobbery attached to the user-friendly program, referring to "the machismo of software" (Tavana 2015). It is perceived to be an easy program, suitable for girls, in a similar way to perceptions that the bass guitar, like the keyboard, is the female instrument in a rock band, requiring less expertise to play than the electric guitar or drums (Clawson 1999). Yet self-production emphasizes the power of the individual's sonic voice, and is significantly empowering for female artists and composers by allowing them to take direct control of their music, cutting out the middle-men who might alter their creative vision by acting as ventriloquists (and also potentially threatening the job security of more traditional male producers).

\section{Women Studio Practitioners Mediate Male Artists}

Given that the voices and lyrics we currently hear in popular music are predominantly mediated by men, resulting in male ventriloquism, one can ask whether a future with more female engineers, producers, and A\&R personnel in the pop music industry would cause a corresponding act of female ventriloquism. The women producers who spoke to me were often aware of the ways their gender affected their recording sessions. The main issues included offensive lyrics (Felix Mackintosh, JPL), sounding personally engaging to the producer (Susan Rogers, JPL, Isobel Campbell), and the effects of a nurturing environment on the studio performance (Miss Melody, Lauren Deakin Davies); conversely, for some, gender was regarded as irrelevant and there was no real difference between recording male or female voices (Olga Fitzroy, Hannah).

Firstly, the recording of potentially contentious lyrics led to some interesting discussions between producers and their clients. Felix Mackintosh, an independent dance music and electronic producer and mix engineer, developed her early career in community recording organizations in the 1990s where what she calls "negative language" was forbidden. In the community studio Ovatones, the 'n-word' was unacceptable. Unusually, all of the studio engineers were women, and this forced a frank dialogue about sexist and racist language. Felix says:

\footnotetext{
Obviously we were having artists like Eminem coming up. It was very ambiguous because in one way it seemed very misogynist, and then in some ways it seemed quite funny. So yes: I have worked with artists some of whose lyrics about women weren't particularly suitable, but on the other hand at that point they were in a female studio so they were quite aware of it themselves, so it brought up a conversation (...) what I used to get was people looking really doubtful when they walked into the room, and then being really happy to come back. (Mackintosh 2012)
}

Similarly, JPL is an R\&B producer who often has long-term working relationships with her artists. She began her career as a rapper, after initially studying psychology 
at Middlesex University. Later she worked with Alexandra Burke and the male singer Zalon, who sang back-up vocals for Amy Winehouse. She now runs her own studio in north London. Her strategy with rappers' language was to say "Save that for live, let's keep it clean for your record". The artists respected her advice because her own rapping skills meant she could give them detailed feedback on their flow and delivery. I wondered whether any of her male artists felt that she was taking the aggression out of their music, perhaps making them unmanly in the process:

I've worked with some very risky rappers and they love it, because when I'm ready I can swear like a paratrooper so we can go there. And one thing people have said to me is that I speak to people in a language that they understand. (JPL 2014)

The sexual content in men's singing and lyrics is something that JPL negotiates. On one occasion, Zalon was exercising self-restraint in both his performance and his lyrical approach. She commented:

I always say to men, if a woman likes a man, a man can get away with saying almost anything to her. It's when we don't like you it's like, 'What did he say? That's a bit out of order, isn't it!'. So we were able to bring that dynamic to the song writing, and some of the maybe more risqué kind of lyrics: not as in cursing or anything like that, but 'take me to bed' kind of lyrics. We can push the boundary on that. (JPL 2014)

Interestingly, the above conversation illustrates JPL encouraging Zalon to stop feeling restrained by the fact that he is recording with a female producer. She is giving him permission to express his sexuality. This is an unusual reversal of conventional gendered studio etiquette that, were it put into practice the other way around, might potentially feel threatening to the artist. However, the male artists that JPL works with appear to enjoy the reversal of roles, and of course once they leave the studio for the outside world, their normal gender roles resume.

The producer and songwriter Isobel Campbell probably comes closest to overt female/male ventriloquism of any of the producers that I interviewed. Formerly a member of the British band Belle and Sebastian, she chose to produce Mark Lanegan because of her response to his voice as a listener: "Mark's voice inspires me, to the point of obsession (...) The first time I saw him perform, I was shocked by how much pain there was in his voice; it was so moving" (Chick 2010). It is notable that Lanegan once refused to perform one of Campbell's songs:

\footnotetext{
"Mark thought it was too 'suggestive'," she laughs. "He didn't realise what he was singing until halfway through, then he stopped and said, 'I can't sing this!'" "She says stuff in a certain way that I probably naturally wouldn't," says Lanegan.

"He said it would probably have been OK if I was singing it" (Chick 2010).
}

This interesting reversal of gender roles demonstrates a negotiation that has not placed power completely in Campbell's hands as a producer. Lanegan's relative power within their working relationship allowed him to refuse to sing lyrics that he felt uncomfortable with, which reflects a very different working relationship to that of, for instance, Darlene Love and Phil Spector. In Chick's interview, Campbell is clear about her intention to speak through Lanegan's emotional vocal style as he voices her lyrics, stating that "My songs are drawn from my life, but his voice is 
perfect at narrating them, at expressing them". Wolfe, in her writing about media reporting and its relationship with Campbell's journey from singer songwriter to producer, mentions the criticisms of Campbell's own voice by various reviewers; it is possible, therefore, that she uses Lanegan's more emotional voice as an "authentic conduit to the Americana her songs seek to evoke" (Chick, cited by Wolfe 2016: 115). Campbell uses Lanegan's voice as a mouthpiece, effectively taking on the role of ventriloquist herself. In her interview for the author she described the reason for wanting autonomy in the studio by pinpointing a moment in her earlier career, when the studio engineer refused to put one of her suggestions into practice. She was working with band member Chris Geddes, and she said:

I could often hear specific sounds in my head and I'd try and convey them to the studio engineer and often he wouldn't quite understand or capture what I was getting at (...) I remember Chris and I begging one particular engineer to distort a vocal we were recording to tape and the engineer was getting flustered and uncomfortable. Both Chris and I are big soul, Motown, Stax and Northern Soul fans and quite often on these great classic $45 \mathrm{~s}$ the vocal was recorded hot to tape. It may have been a mistake but it sounded GREAT! Nonetheless, regardless of whither [sic] the distortion was a mistake or not, these vocals recorded hot to tape were very pleasing to the ear (...) in our opinion. Chris and I knew technically what we were looking for in the studio but the engineer was visibly squirming and really did not want to do this, and in the end he never did distort that vocal. (Campbell 2014)

Considering different aesthetic values cultivated in the studio by women, in terms of hearing music, the opinions of female producers and engineers differ about whether there is an inherent gender difference in their response to recordings. One of the sound engineers interviewed was convinced that women's bone structure gave them an advantage as far as aural perception was concerned, and had discussed this with her male mentor. This opinion was shared by the US engineer Carla Olson in an interview with Howard Massey (2009). When asked if there was a "genetic reason that causes women to hear things differently from men", she responds:

I don't know, but I do find it to be true, and male engineers tell me that all the time, too. It's not that we hear things totally differently; it's a lot more subtle than that, like the way things sit in a mix. A lot of the times the way I mix a vocal is different from the way a male engineer might do it - they'll actually say to me, "Wow, I wouldn't have thought of doing it that way". I don't knowmaybe it's a physical thing. Or maybe it's just a vulnerability thing (2009: 129130).

Quite possibly alleged differences in hearing between the genders could be used negatively to justify the continued domination of male studio engineers and producers in the industry, but the grime producer Miss Melody (whose clientele is, she estimates, 85\% male), regards her essentially female approach as a positive factor. Asked about the female ear in her interview with the author, she describes nurturing not only the artist, but also the vocal recording itself. Does she believe that she has a different way of listening than a male producer in the genre?

A hundred percent! Because I look out for different things: tonations, diction, believability. There's certain things I want this recording to be like: certain attention to detail. The reason why I personally believe that I became so 
popular is because of what other males told me (...) there's just a level of care, a level of nurturing that I give to the vocal that they just don't see with other engineers that they've worked with. I will analyse the hell out of what they are saying and I'Il take every single tiny syllable and if I just want to emphasize the smallest little point I'Il do it by either dropping out the beat, or just echoing slightly into the background maybe a word or the end of something that they've said, or elongate or stretch something; and those are the kind of lengths that I would go to that other people would just kind of pass by. (Miss Melody 2018)

Miss Melody also felt that male artists felt more comfortable being criticized by a woman than they would by a man, where the criticism might be perceived as competitive aggression. Lauren Deakin Davies, who predominantly works with singer songwriters, also feels that a less competitive recording environment gets better results. Identifying herself as gay, she remarks:

Male sexiness isn't really something I'm looking out for. Something I find myself doing is helping men to sing falsetto better, or sing higher notes. Maybe they've sung a lot by themselves and so they go [sic] low, and they get to a high part and they really struggle and I feel like, 'I can help you, teach you to hit those notes properly'. If they were in a studio with a [male producer] and were trying to hit a high note and they couldn't, I feel like they'd be worried that the man was judging them and even taking the piss out of them for singing a high part. I'm really supportive. (Deakin Davies 2018)

Olga Fitzroy, a British engineer who has music, TV and film credits to her name, has a more practical view, which she brought up in response to my question about recording male vocalists:

Question: Have you ever reversed the normal situation where a male engineer records a female artist, by recording a male vocalist? If so, what led to this decision being made, and do you think you heard his voice differently?

Answer: Quite often - It seems to me that most singers in bands are male, so I've often recorded male vocalists. I think the decision was made because I happened to be the person that had been booked to make the recording, perhaps I'd worked with that artist or someone connected with that artist before. If I'm trusted to record drums, guitar and strings, why not vocals? I don't think women in general hear things particularly differently to men. I've read articles saying that women have better hearing than men on average, but I don't think being a good engineer is about what frequencies are audible to you, it's more about aesthetic choices, and being competent. (Fitzroy 2016)

Likewise, Hannah (pseudonym), who has specialized in recording rock vocalists for many years, feels strongly that her decisions about sonic aesthetics are not influenced by gender:

Question: When you record male vocals, how aware are you of making them sound appealing to female listeners/audiences, and how does this affect the way you approach the sound?

Answer: I have never ever, ever thought about making male vocals sound more appealing to female listeners. I just go for what sounds good for whoever is listening and what suits the music. A good well-executed performance is the most important thing. (Hannah 2016) 
In a similar way to Fitzroy, she aims for invisibility, or rather inaudibility, as a mediator. The emphasis on the performance (and therefore the performer) conceals her role. Miss Melody also identifies with this approach, and brought it up unbidden: "That is how I look at myself, as a translator. You bring me something and it's about me interpreting it correctly and bringing it back out to the public exactly the way you want it to be heard" (Miss Melody 2018). This is ethos is also practised by country music producers like Paul Worley, who refers to himself as "a facilitator and a translator" (Frith and Zagorski-Thomas 2012: 132).

It would be tempting to conclude that the women interviewed by the author who identified themselves as engineers (Olga Fitzroy, Hannah, and Miss Melody) are less concerned with awareness of their gender as mediators and more concerned with simply recording sound, than those who regard themselves as producers (Felix Mackintosh, JPL, and Lauren Deakin Davies). However, Francois Cooren (2010) warns us that in all human engagement, ventriloquism appears to be a "ubiquitous phenomenon in interaction and dialogue" (2010: 134), that is ultimately deniable by both the ventriloquist and the dummy (ibid. 103). This suggests that the concept of the imperceptible producer may be a myth, and implies that despite changes in the gender balance in studio practice, ventriloquism in the studio will still be embedded into popular music production.

\section{Conclusion}

In conclusion, we can imagine that women producers and engineers will become just as capable of becoming ventriloquists for male artists as men have been for female artists. Aspects of ventriloquism are inherent in the act of production. In the cases of JPL and Isobel Campbell, the process of ventriloquism is consciously practiced to differing degrees. Even as interpreters and translators, engineers' roles involve an element of mediation whose aesthetics are affected by what "sounds good", as Hannah says, and this is a subjective choice. However, my interviews suggest a willingness by women studio professionals to consider the implications of gender mediation at the outset of the recording process, and this is probably because questioning of gender roles is an inevitable part of being a woman in a male dominated profession.

The introduction of female engineers and producers into mainstream popular music recording is still a relatively new phenomenon whose longevity depends on a combination of their own staying power and the industry's will to change. There is a reluctance to progress even in music technology teaching in UK secondary education, as Victoria Armstrong's research has shown (Armstrong 2011). A feeling still exists, according to the writer and producer Howard Massey, that there are "simply not that many women who are interested in doing this for a living" (Askar 2005). This is challenged by Cordelia Fine's observation that "As the arguments that women lack the necessary intrinsic talent to succeed in male dominated occupations become less and less convincing, the argument that women are just less interested has grown and flourished" (2010: 52). The women that I interviewed are not only highly skilled but also resilient in the face of challenging work environments. They are definitely interested in sustaining their choice of career. I am very grateful to them for their willingness to address the questions that I asked, although some of the interviewees avoided overt statements about gendered studio practice. Discussion about this might colour their future reputation in the (still male dominated) music industry. It was notable that Susan Rogers in particular could so comfortably talk about her physical response to sonically attractive male voices. 
This was honest and open of her and reflects the confidence she has in her professional standing.

More optimistically, a groundswell of women-led organizations that support female studio practitioners has grown steadily since the end of the $20^{\text {th }}$ century, from local organizations (such as the Huddersfield organisation) to much larger global communities. As Wolfe (2012) has observed, self-production and its focus on the power of the individual's sonic voice is an empowering practice for women musicians and has the potential to circumvent the problem of ventriloquism. This particularly resonates in electronic music genres. The internet community female:pressure.net supports electronic music produced by over 1700 women from 66 countries and which, originally inspired by Björk's public statements about her own technical agency in the production of her music, set up a Tumblr site featuring photographs of women musicians with their kit. ${ }^{3}$ The sheer size of female:pressure indicates that women are not only "interested in doing this for a living" but also highly skilled and successful, actively enjoying the manipulation of sound. As more women gain control of their own sonic identity, we are more likely to hear their authentic voices, rather than those filtered through male ventriloquists.

\section{Endnotes}

1 Since Pia Palme coined this concept, the website has changed and subsequently, the thread where it first appeared is no longer available. However, the author discussed this concept again with Palme through email.

2 Marni Nixon, for example, dubbed singing parts in West Side Story, My Fair Lady and many other musical films.

3 Other supportive organizations include the San Francisco-based Women's Audio Mission in the US and in the UK. As the organization Sound Women closed due to lack of funding, it is to be hoped that others, such as Katia Isakoff's Women Produce Music will replace some of their activities.

\section{Acknowledgements}

With thanks to Sarah Killick for her transcription work.

\section{References}

\section{Bibliography}

Armstrong, V. 2011. Technology and the Gendering of Music Education. Farnham and Burlington: Ashgate.

Attali, J. 1999. Noise: the political Economy of Music. Minneapolis/London: University of Minneapolis Press.

Auner, J. 2003. 'Sing it for Me': Posthuman Ventriloquism in Recent Popular Music. Journal of the Royal Musical Association, 128 (1): 98-122. Accessed 30 June 2018.

BBC, 2013. 'Charlotte Church attacks sexist music industry', BBC News, 15 October. http://www.bbc.co.uk/news/entertainment-arts-24528022 Accessed 14 January 2018.

Born, G. and Devine, K. Eds. 2016. Gender, Creativity and Education in Digital Music and Sound Art. Contemporary Music Review, 35 (1): 115-129 https://doi.org/10.1080/07494467.2016.1177255

Bradby, B. - 
1990. Do-Talk and Don't-Talk: The Division of the Subject in Girl Group Music in Frith, S. and Goodwin, A. Eds. (1998) On Record: Rock, Pop and the Written Word. London and New York: Routledge: 341-368.

1993. Sampling Sexuality: Gender, Technology and the Body in Dance Music.

Popular Music 12(2): 155-176. https://doi.org/10.1017/S0261143000005535

Bourdieu, P. 2001. Masculine Domination. Cambridge: Polity.

Butler, J. 1993. Imitation and Gender Insubordination. In H. Abelove, M. A.

Barale and D. Halperin Eds. The Lesbian and Gay Studies Reader. New York: Routledge: 307-320.

Chick, S. 2010. 'I write the songs; he's the eye candy': Isobel Campbell and Mark Lanegan. The Guardian, 28 October.

https://www.theguardian.com/music/2010/oct/28/isobel-campbell-marklanegan-interview Accessed 10 March 2018.

Clawson, M. 1999. When Women Play the Bass: Instrument Specialization and Gender Interpretation in Alternative Rock Music. Gender and Society 13(2): 192-211. https://doi.org/10.1177/089124399013002003

Cooren, F. 2010. Action and Agency in Dialogue Amsterdam/Philadelphia: John Benjamins Publishing.

Dickinson. K. 2001. 'Believe'? Digitalised Female Identity and Camp. Popular Music 20/3: 33-347 https://doi.org/10.1017/S0261143001001532

Easlea, D. 2004. Everybody Dance: Chic and the Politics of Disco. London: Helter Skelter.

Fine, C. 2010. Delusions of Gender: The Real Science Behind Sex Differences. London: Icon Books.

Fleeger, J. 2014. Mismatched Women: the Siren's Song through the Machine. Oxford: Oxford University Press.

Frith, S. and Goodwin, A. Eds. 1998. On Record: rock, pop and the written word. London and New York: Routledge.

Frith, S. and Zagorski-Thomas, S. Eds. 2012. The Art of Record Production: an introductory Reader for a new Academic Field. Farnham: Ashgate.

Gadir, T. 2016. Resistance or Reiteration? Rethinking Gender in DJ Cultures in Born, G. and Devine, K. Eds. 2016. Gender, Creativity and Education in Digital Music and Sound Art. Contemporary Music Review, 35 (1): 115-129 https://doi.org/10.1080/07494467.2016.1177255

Goodwin, A. 1992. Rationalization and Democratization in the New Technologies of Popular Music. In Lull, J. Ed. Popular Music and Communication. London: Sage.

Green, L. 1997. Music, Gender, Education. Cambridge: Cambridge University Press.

Greig, C.1989. Will You Still Love Me Tomorrow: Girl Groups from the 50s on... London: Virago.

Katz, M. 2010. Capturing Sound: how Technology has changed Music. Berkeley, Los Angeles, London: University of California Press.

Lawrence, T. 2015. How Loleatta Holloway Became Disco's Most Sampled Artist. electronicbeats.net, October 2 http://www.electronicbeats.net/how-loleattaholloway-became-discos-most-sampled-artist/ Accessed 5 May 2018.

Leonard, M. 2016. Girls at Work: gendered Identities, Sex Segregation and Employment Experiences in the Music Industries. In Warwick, J. and Adrian, A. Eds. 2016. Voicing Girlhood in Popular Music: Performance, Authority, Authenticity New York: Routledge: 37-55.

Love, D. 2013. My Name is Love. New York: William Morrow. 
Lull, J. Ed. 1992. Popular Music and Communication, London: Sage.

Massey, H. 2009. Behind the Glass: top Record producers tell how they Craft the Hits Volume 11. Milwaukee: Backbeat.

Middleton, R. 2006. Voicing the Popular: on the Subjects of Popular Music. New York/Abingdon: Routledge.

Milner, G. 2009. Perfecting Sound Forever: the Story of Recorded Music. London: Granta.

MPG News. 2016. Music Producers Guild Announces its 2016 Award Winners! 4 February. https://www.mpg.org.uk/news/mpg-awards-2016-winners/ Accessed 28 April 2018.

Mulvey, L. 1975. Visual Pleasure and Narrative Cinema. Screen 16 (3): 6-28

Nicholson, R. -

2008. 'Why Björk is right to stand up for female producers'. The Guardian, 27 August.

https://www.theguardian.com/music/musicblog/2008/aug/27/whybjorkisright tostickup Accessed 7 August 2018

2015. 'Chvrches: "We could have sold 200,000 more records if we hid us boys out of view". The Guardian, 20 August.

http://www.theguardian.com/music/2015/aug/20/chvrches-we-could-havesold-200000-more-records-if-we-hid-the-boys-out-of-view Accessed 30 June 2018.

Newman, M. 2018. Where Are All the Female Music Producers? Billboard, 19 January. https://www.billboard.com/articles/business/8095107/female-musicproducers-industry-grammyawards?utm_source=twitter\&utm_source=t.co\&utm_medium=referral Accessed 30/05/2018 Accessed 30 May 2018.

Reddington, H. (forthcoming) Outside the Box: Women Engineers and Producers in the British Pop Music Industry in the early 21st Century. Sheffield: Equinox.

Rodgers, T. 2010. Pink Noises: Women on Electronic Music and Sound. Durham/London: Duke University Press.

Seabrook, J. 2015. The Song Machine: how to make a Hit. New York: Jonathan Cape.

Shepherd, J. 1991. Music as Social Text. London: Polity.

Sillitoe, S.1999. 'Recording Cher's "Believe"'. Sound on Sound, February 1999. https://www.soundonsound.com/techniques/recording-cher-believe Accessed 30 June 2018.

Tavana, A. 2015. Democracy of Sound: Is Garageband Good for Music? Pitchfork.com, 30 September. http://pitchfork.com/features/article/9728democracy-of-sound-is-garageband-good-for-music/ Accessed 28 April 2018.

Théberge, P. 1997. Any Sound You Can Imagine: making Music/consuming Technology. Hanover NH: Wesleyan University Press.

Toynbee, J. 2000. Making Popular Music: Musicians, Creativity and Institutions. London: Hodder Arnold.

Wolfe, Paula -

2012. A Studio Of One's Own: Music Production, Technology And Gender Journal on the Art of Record Production. (7) http://www.arpjournal.com/asarpwp/a-studio-of-one's-own-musicproduction-technology-and-gender/ Accessed 1 August 2018

2016. 'I write the songs. He's the eye candy': the female singer-songwriter, the woman artist-producers and the British Broadsheet press. In Green, S. and Marc, I. Eds. The Singer-Songwriter in Europe: Politics, Paradigms and Place. London and New York: Routledge: 95-109 
Warwick, J. 2004. 'He's Got The Power': the politics of production in girl group music in Whiteley, S. Bennett, A. and Hawkins, S. Eds. Music, Space and Place: popular music and cultural identity Farnham and Burlington: Ashgate

\section{Web Sources}

Askar, P. 2005. 'Howard Massey: Record Producer and Music Industry Author'. Originally published on: blog.lownoiserecords.com. Permanent link: https://web.archive.org/web/20160407185739/http://blog.lownoiserecords.com :80/howardmassey.html Accessed 7 August 2018.

Elliott, M., 2018. Where are all the female producers? Twitter, 24 January. Available from: https://twitter.com/MissyElliott/status/956349994713436160 Accessed 30 June 2018.

Female:pressure http://www.femalepressure.net/fempress.html Accessed 28 April 2018.

Grimes., 2018. Twitter, 8 March. Available from: https://twitter.com/Grimezsz/status/971912926238920704 Accessed 1 August 2018.

M, PRS For Music Online Magazine, 2013. Women in music: round table discussion. 8 March. http://www.m-magazine.co.uk/publishers/women-inmusic/ Accessed 28 April 2018.

Marling, L., 2016. http://www.reversalofthemuse.com Accessed 14 January 2018.

Sound Women, http://www.soundwomen.co.uk Accessed 28 April 2018

The Huddersfield Organisation: http://www.soundandmusic.org/projects/gocompose-huddersfield Accessed 13 August 2018

\section{Discography}

Aretha Franklin. 1967. "You Make Me Feel Like) A Natural Woman", Atlantic, September, USA.

Beyoncé. 2011. "Run the World (Girls)", Columbia, USA.

Black Box. 1989. "Ride On Time", Groove Groove Melody, USA.

Cher. 1998. "Believe", WEA/Warner Bros, USA.

\section{Film}

Singin' in the Rain. 1953. Dir. Stanley Donen and Gene Kelly, MGM.

\section{Interviews}

The interviews were conducted between 2009 and 2018. Specific ages were not requested after observing that male producers were not usually asked to provide their ages when being interviewed. The interviewees were mainly found through personal contacts and recommendations and also through Internet searches. Two women requested anonymity, and the pseudonym Hannah has been used to comply with this request. The interview duration varied from half an hour to an hour, and they were conducted in a venue of the interviewee's choice (usually a quiet café). Some were conducted by email if the interviewee was abroad or very 
busy. The questions were semi-structured; additional questions were added as the project progressed. If the opportunity arose to conduct interviews with US or other producers this was taken, but most were with predominantly British studio professionals, as the author is based in Britain. Male producers were not interviewed. During the period in which the interviews were undertaken, both media curiosity about the lack of women producers and engineers, and changing practices in popular music production and distribution, increased the visibility of women producers and engineers.

Colleen Murphy. 2014. Interview by Helen Reddington, London, May. Felix Mackintosh. 2012. Interview by Helen Reddington, London, September. Hannah. 2016. Interview by Helen Reddington, email, September. Isobel Campbell. 2014. Interview by Helen Reddington, email, September. JPL. 2014. Interview by Helen Reddington, London, April.

Lauren Deakin Davies. 2018. Interview by Helen Reddington, London, March. Miss Melody. 2018. Interview by Helen Reddington, London, February. Olga Fitzroy. 2016. Interview by Helen Reddington, email, July. Susan Rogers -

2015. Interview by Helen Reddington, email, January.

2014. Personal Conversation at the ARP Conference, Oslo, December. 